\title{
Ocular dimensions in the heredity of angle-closure glaucoma
}

\author{
A. TOMLINSON AND D. A. LEIGHTON \\ Department of Ophthalmology, Manchester Royal Eye Hospital
}

It has long been recognized that heredity plays a part in the aetiology of glaucoma. François and Heintz-de Bree (1966) postulated a dominant heredity in open-angle glaucoma. They noted a $9^{8}$ per cent. penetrance for a dominant gene in some families, but admitted that in other families the penetrance for a dominant gene was very low. Armaly (1967a), on the other hand, suggested a polygenic inheritance in open-angle glaucoma. A similar controversy exists in diabetes mellitus, where Vallance-Owen ( 1967 ) suggests dominance, and Falconer (1965) a multifactorial aetiology.

The pattern of angle-closure glaucoma among affected families also shows a variable prevalence. There have been a few reports of a high prevalence with transmission through two or more generations suggesting an autosomal dominant pattern, e.g. Posner and Schlossman (1949), Probert (1952), Weekers, Gougnard-Rion, and Gougnard (1955), and Lowe (1964). Autosomal recessive inheritance has been reported by Waardenburg (1949) and Biró (195I). However, in many families, only one affected member is found. If a dominant heredity is to be postulated in angle-closure as in open-angle glaucoma, a very variable and generally low penetrance of the gene must be assumed to explain the very variable prevalence of the condition in different families. Lowe (1970b) suggested a polygenic aetiology in angle-closure glaucoma.

Angle-closure glaucoma occurs most frequently, but not exclusively, in eyes which are hypermetropic (Sugar, I 94I ; Davenport, I 959; Lowe, I96I). It is, of course, the typical ocular dimensions found in hypermetropia which play such an important part in the aetiology of angle-closure glaucoma. Hence hypermetropia is associated with a shallow anterior chamber (Rosengren, I950; Sorsby, Benjamin, Davey, Sheridan, and Tanner, 1957). It is interesting that the higher degrees of hypermetropia are found in small eyes with relatively flat corneae (Stenström, 1948; Sorsby and others, I957). The influence of ocular dimensions in angle-closure glaucoma has been reported by several authors.

\section{ANTERIOR CHAMBER DEPTH}

This is reduced in angle-closure glaucoma compared to the normal (Rosengren, I931 ; Törnquist, 1956; Lowe, 1968; Storey and Phillips, I97 I). Priestley Smith ( I91 I) attributed a shallow anterior chamber to the presence of a large lens in a small eye. Anterior chamber depth decreases with increasing age (Priestley Smith, I883; Raeder, 1922; Rosengren, 1930).

CRYSTALLINE LENS

This is larger in its antero-posterior axis in angle-closure glaucoma than in the normal (Aizawa, I96o; Gernet and Jürgens, I965; Lowe, r969a; Storey and Phillips, I97 I). With advancing age the lens increases in size (Priestley Smith, I883). Lowe ( $1970 a, b)$ suggested that the thickening lens contri- 
buted further to shallowness of the anterior chamber because, with increasing age, its anterior surface becomes more anteriorly sited. When a critical amount of shallowing of the anterior chamber has occurred, iris bombé leads to angle-closure.

\section{CORNEA}

Lowe (1969b, c) suggested that the curvature and thickness of the cornea did not contribute to shallowness of the anterior chamber in angle-closure glaucoma, al though the radius of the cornea was found to be less in glaucomatous than in normal eyes (Törnquist, 1957; Grieten and Weekers, 1962; Lowe, 1969a). Grieten and Weekers (1962) and Storey and Phillips (1971) have shown, however that the corneal diameter in the eye with angle-closure glaucoma is smaller than in the normal eye of the same age and refraction. This difference probably contributes to shallowness of the anterior chamber.

The effect of corneal height on the depth of the anterior chamber has been considered by Delmarcelle, Collignon-Brach, and Luyckx-Bacus (1970) and by Storey and Phillips (1971); the anterior chamber is found to be shallower in eyes which have small corneal heights. Delmarcelle, Collignon-Brach, and Luyckx-Bacus (1969) showed that corneal height was a function of corneal radius and diameter. Storey and Phillips (197I) reported that the corneal height was less in eyes with angle-closure glaucoma than in the normal.

\section{AXIAL LENGTH OF THE EYEBALL}

This was found by Lowe (1969a) and Storey and Phillips (197I) to be less in angle-closure glaucoma than in the normal.

\section{Objectives}

It is clear that certain anatomical features of the eyeball are of importance in angle-closure glaucoma. Anterior chamber depth (Törnquist, I953), corneal dimensions, lens thickness, and axial length (Sorsby, Sheridan, and Leary, 1962; Sorsby and Fraser, 1964) are genetically determined. It was therefore considered of interest to investigate these dimensions in patients with angle-closure glaucoma and in the first-degree relatives of patients with this condition. A similarity in these dimensions between patients and their relatives may explain a predisposition to, or risk of acquiring, the condition in these relatives, and conversely any dissimilarities many explain why many relatives do not become affected, thus clarifying the role of ocular dimensions in the aetiology of angle-closure glaucoma.

\section{Methods}

\section{Subjects}

There were 108 in all. These comprised:

(I) Sixteen patients with angle-closure glaucoma

(2) Fourteen siblings of patients with angle-closure glaucoma

(3) 29 offspring of patients with angle-closure glaucoma

(4) 49 normal controls.

Each subject in Groups I, 2, and 3 was matched for sex, age, and refractive error with a control subject from Group 4 within the age range +9 to -7 years and to within one dioptre of the best spherical refraction. Some control subjects were used more than once, i.e. they were matched with a subject from Groups I, 2, and 3; this accounts for the smaller number of normal controls (49) than the total number in the other three categories combined (59). 
In the comparison of the dimensions of affected and unaffected siblings, satisfactory control oof age and refractive error was possible in seven pairs, but control of sex was achieved in four pair only. The dimensions of two affected female siblings were compared with those of their unaffected male siblings, and the dimensions of one male index patient with those of his unaffected female sibling.

Certain ocular dimensions were measured from both eyes in subjects from Groups I, 2, and 3 and from one eye only chosen at random in the 49 normal control subjects.

\section{(1) Index patients with angle-closure glaucoma.}

The dimensions from one eye of sixteen patients with angle-closure glaucoma were analysed statistically ( 9 right, 7 left). The affected eye was used where only a predisposition was present in the other eye; if both eyes were affected, the eye for analysis was chosen at random. The ages of the patients varied between 53 and 79 years; eleven were female and five male. The refractions ranged from $+3 \cdot 75$ to $-2 \mathrm{D}$ sph. All eyes had had either a peripheral or sector iridectomy. In none of them had a drainage operation been done. One patient was being treated with pilocarpine dropsir This medication was discontinued 48 hours before examination, as Wilkie, Drance, and Schulzeki (1969) have shown that a shallowing of the anterior chamber can result from treatment with miotics

All patients in this group had at least one relative (sibling or offspring) who was also included ing this survey.

\section{(2) Siblings of patients with angle-closure glaucoma}

The dimensions from one eye, chosen at random (6 right, 8 left), of fourteen siblings of patients with $\overrightarrow{0}$ angle-closure glaucoma, seven of whom were related to patients in Group I, were used for analysis: ${ }^{\omega}$ Their ages ranged from 46 to 73 years; nine were female and five male. The refractions range from +4 to $-0.5 \mathrm{D}$ sph.

\section{(3) Offspring of patients with angle-closure glaucoma}

29 were included, of whom fourteen were related to patients in Group 1 . The dimensions from one eye, chosen at random ( 16 right, 13 left) were used for analysis. The offsprings' ages ranged from? I 7 to 57 years; fourteen were female and fifteen male. The refractions ranged from +5 to $-0 \cdot 25 \mathrm{D} \mathrm{sph}$.

(4) 'Normal' control subjects.

There were twenty males and 29 females; their ages ranged from 18 to 60 years and the refractions from +6 to $-1 \cdot 75 \mathrm{D}$ sph. They had clinically normal eyes and no evidence of glaucoma was founf in them, nor was there a known family history of glaucoma. In each of the 49 controls, the dimensionsin were recorded from one eye only, chosen at random (24 right, 25 left).

\section{Ocular dimensions}

The following were recorded for each subject by the methods indicated:

(i) Refraction determined objectively and subjectively.

(ii) Mean central corneal curvature, i.e. $\frac{\text { (horizontal }+ \text { vertical radius) }}{2}$ by Zeiss keratometry.

(iii) Horizontal corneal diameter from a colour photograph of the anterior surface of the्ष eye.

(iv) Corneal thickness by the Type I attachment for the Haag-Streit 900 slit lamp.

(v) Depth of the anterior chamber measured from the anterior surface of the cornea to the anterior surface of the lens by the Type II attachment for the Haag-Strei $\overrightarrow{\mathbb{Q}}$ goo slit lamp. 
(vi) Applanation tension recorded with the attachment for the Haag-Streit slit lamp.

(vii) Thickness of the crystalline lens $\}$ from an anterio-posterior axis trace of the eye

(viii) Length of the vitreous body $\}$ obtained by A-scan ultrasonography

(ix) Axial length of the eyeball -found from the addition of (v), (vii), and (viii).

(x) Relative lens position calculated from the formula,

(see Lowe, 1970a)

$$
\frac{\text { anterior chamber depth }+\frac{1}{2} \text { lens thickness }}{\text { axial length }}
$$

(xi) Corneal height calculated from the formula,

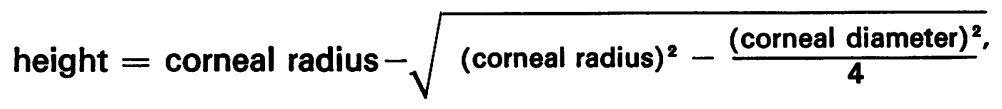

(see Delmarcelle, and others, ig69).

(xii) Axial length of scleral envelope calculated by subtracting corneal height from axial length (see Storey and Phillips, 1971).

\section{Results}

The Wilcoxon matched pairs signed ranks test (Siegel, I956) was used to analyse the data. This test was particularly appropriate because each index patient, a sibling, or an offspring had been paired or matched for sex, age, and refractive error with a control subject.

The mean values found for each dimension in the index, sibling, offspring, and control subjects are shown in Tables I to III, together with the results of the statistical test and the level of significance of the differences found between the samples.

The comparisons between the dimensions for the angle-closure glaucoma patients or relatives with the control subjects will be dealt with three separate sections, I, II and III.

Table I Mean values recorded for ocular dimensions of a group of patients with angle-glaucoma and of a grow

The values obtained for the two groups were compared by a Wilcoxon matched-pairs signed-ranks test; the

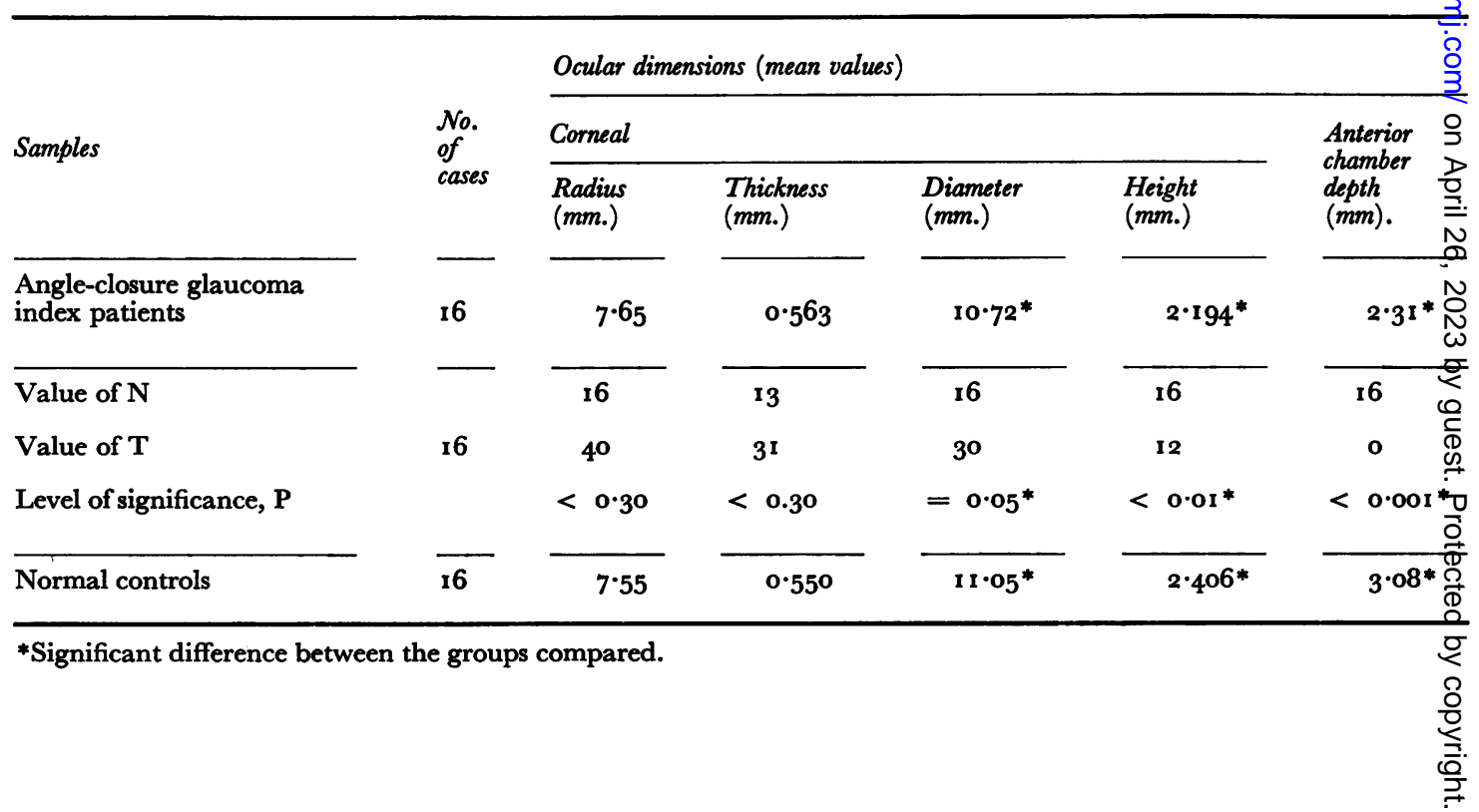


In Section IV a comparison is made between affected and unaffected members of the same sibship.

I. OGULAR Dimensions OF PATIENTS With ANgle-glosure glaucoma COMPARED WITH THOSE OF NORMAL CONTROL SUBJECTS.

The results are shown in Table $I$. The following dimensions differed significantl $(\mathrm{P}<0 \cdot 05)$ in angle-closure glaucoma compared to the normal. The corneal height and corneal diameters were smaller $(\mathrm{P}<0 \cdot 0 \mathrm{I}$ and $\mathrm{P}<0.05$, respectively $)$, the anterio chamber shallower $(\mathrm{P}<0 \cdot 00 \mathrm{I})$, the lens thicker $(\mathrm{P}<0 \cdot 00 \mathrm{I})$ and its position relatively further forward $(P<0.00 \mathrm{I})$, and the axial length smaller $(\mathrm{P}<0.05)$ in angle-closure glaucoma than in the normal.

II. OGULAR Dimensions OF SIBLINGS OF PATIENTS With ANGLE-Glosure GLAUCOMA GOMPARED WITH THOSE OF NORMAL CONTROL SUBJEGTS.

The results are shown in Table II. A similar picture is seen in the comparison of the dimensions of siblings and the normal, as for the index patients with angle-closure glaucomal compared to the normal above. Corneal height and diameter were again smalle? ( $\mathrm{P}<0.02$ and $\mathrm{P}<0.05$, respectively) than in the controls. The anterior chamber depth was shallower $(\mathrm{P}<0 \cdot 0 \mathrm{I})$, the lens thicker $(\mathrm{P}<0 \cdot 00 \mathrm{I})$, and the eyeball shorte $(\mathrm{P}<0.05)$ in the siblings than in the normal. The lens was not, however, sited and further forward than in the latter.

III. OGULAR DIMENSIONS OF OFFSPRING OF PATIENTS WITH ANGLECLOSURE GLAUGOMA COMPARED WITH THOSE OF NORMAL GONTROL SUBJEGTS.

The results are shown in Table III. Corneal height and diameter in the offspring were both found to be significantly smaller than in normals $(\mathrm{P}<0.00 \mathrm{I}$ and $\mathrm{P}<0.05$ respec 3 tively). The anterior chamber was also significantly shallower $(P<0 \cdot 02)$ and the lens

of normal control subjects matched for age (within +9 to -7 years), sex, and refraction (within $\pm \mathrm{I} \cdot \mathrm{o}$ dioptre) value of $\mathcal{T}$ is shown together with the number of ranked pairs with a sign $(\mathcal{N})$ and the level of significance of differences found

\begin{tabular}{|c|c|c|c|c|c|c|}
\hline $\begin{array}{l}\text { Lens } \\
\text { thickness } \\
(m m .)\end{array}$ & $\begin{array}{l}\text { Relative } \\
\text { lens } \\
\text { position }\end{array}$ & $\begin{array}{l}\text { Vitreous } \\
\text { length }(\mathrm{mm} .)\end{array}$ & $\begin{array}{l}\text { Axial } \\
\text { length (mm.) }\end{array}$ & $\begin{array}{l}\text { Length } \\
\text { of scleral } \\
\text { envelope } \\
(m m .)\end{array}$ & $\begin{array}{l}\text { Mean } \\
\text { age } \\
\text { (yrs) }\end{array}$ & $\begin{array}{l}\text { Mean } \\
\text { refraction } \\
\text { (dioptres) }\end{array}$ \\
\hline $5 \cdot 23^{*}$ & $0.224^{*}$ & 14.52 & $22 \cdot 06^{*}$ & $19 \cdot 86$ & $66 \cdot 50$ & $+1 \cdot 09$ \\
\hline 16 & 16 & I6 & 16 & I6 & 16 & 14 \\
\hline 3 & Io & $3^{2}$ & 30 & $43 \cdot 5$ & 45 & 63 \\
\hline$<0.001^{*}$ & $<0.001^{*}$ & $=0.07$ & $=0.05^{*}$ & $<0.20$ & $<0.30$ & $<0.407$ \\
\hline $4 \cdot 67^{*}$ & $0 \cdot 24^{\circ *}$ & $14 \cdot 86$ & $22 \cdot 5^{8 *}$ & $20 \cdot 40$ & $64 \cdot 88$ & $+\mathbf{r} \cdot 00 \frac{\Omega}{\mathbb{D}}$ \\
\hline
\end{tabular}


Table II Mean values recorded for ocular dimensions of a group of siblings of patients with angle-closate The values obtained for the two groups were compared by a Wilcoxon matched-pairs signed-ranks test;

\begin{tabular}{|c|c|c|c|c|c|c|}
\hline \multirow{3}{*}{ Samples } & \multirow{3}{*}{$\begin{array}{l}\text { No. } \\
\text { of } \\
\text { cases }\end{array}$} & \multicolumn{4}{|c|}{ Ocular dimensions (mean values) } & $\begin{array}{l}\frac{10}{+} \\
\frac{0}{c}\end{array}$ \\
\hline & & \multicolumn{4}{|l|}{ Cornea } & \multirow{2}{*}{ 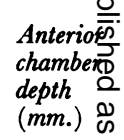 } \\
\hline & & $\begin{array}{l}\text { Radius } \\
(\mathrm{mm} .)\end{array}$ & $\begin{array}{l}\text { Thickness } \\
(\mathrm{mm} .)\end{array}$ & $\begin{array}{l}\text { Diameter } \\
(\mathrm{mm} .)\end{array}$ & $\begin{array}{l}\text { height } \\
(m m .)\end{array}$ & \\
\hline $\begin{array}{l}\text { Angle-closure glaucoma } \\
\text { siblings }\end{array}$ & 14 & $7 \cdot 7 \mathrm{I}$ & $0 \cdot 562$ & $10 \cdot 89^{*}$ & $2 \cdot 26$ I & $2 \cdot \overrightarrow{T_{0}^{* *}}$ \\
\hline Value of $N$ & & 14 & 13 & 14 & 14 & \\
\hline Value of $T$ & 14 & $47 \cdot 5$ & $42 \cdot 5$ & 15 & $18 \cdot 5$ & $4.5:$ \\
\hline Level of significance $P$ & & $<0.50$ & $<0.50$ & $<0.02^{*}$ & $<0.05^{*}$ & $<0.0$ जै $^{*}$ \\
\hline Normal controls & 14 & $7 \cdot 68$ & 0.564 & $11 \cdot 18^{*}$ & $2 \cdot 421^{*}$ & $3 \cdot 17^{*}$ \\
\hline
\end{tabular}

Table III Mean values recorded for ocular dimensions of a group of offspring of patients with angle-closupe

The values obtained for the two groups were compared by a Wilcoxon matched-pairs signed-ranks test;

\begin{tabular}{|c|c|c|c|c|c|c|}
\hline \multirow{3}{*}{ Samples } & \multirow{3}{*}{$\begin{array}{l}\text { No. } \\
\text { of } \\
\text { cases }\end{array}$} & \multicolumn{5}{|c|}{ Ocular dimensions (mean values) } \\
\hline & & \multicolumn{4}{|l|}{ Cornea } & \multirow{2}{*}{ 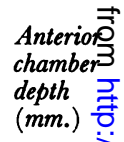 } \\
\hline & & $\begin{array}{l}\text { Radius } \\
\text { (mm.) }\end{array}$ & $\begin{array}{l}\text { Thickness } \\
(\mathrm{mm} .)\end{array}$ & $\begin{array}{l}\text { Diameter } \\
(\mathrm{mm} .)\end{array}$ & $\begin{array}{l}\text { Height } \\
(m m .)\end{array}$ & \\
\hline $\begin{array}{l}\text { Angle-closure glaucoma } \\
\text { offspring }\end{array}$ & 29 & $7 \cdot 78$ & $0 \cdot 557$ & $10 \cdot 92^{*}$ & $2 \cdot 244^{*}$ & $2 \cdot \frac{0}{9} \cdot$ \\
\hline Value of $\mathrm{N}$ & & 28 & 27 & 29 & 29 & 29 \\
\hline Value of $T$. & 29 & $188 \cdot 5$ & 190 & 87 & $5^{\mathbf{I}}$ & 95 옥 \\
\hline Level of significance $P$ & & $<0.50$ & $<0 \cdot 10$ & $<0.05^{*}$ & $<0.001^{*}$ & $<0.0 \frac{D}{3}$ \\
\hline Normal controls & 29 & $7 \cdot 80$ & $0 \cdot 560$ & I $1 \cdot 33^{*}$ & $2 \cdot 445^{*}$ & $\begin{array}{c}3 \cdot 28^{*} \\
N\end{array}$ \\
\hline \multicolumn{6}{|c|}{$\begin{array}{l}\text { significantly thicker }(P<0 \cdot 02) \text { than in the control subjects. } \\
\text { cantly further forward than in the normal. }\end{array}$} & 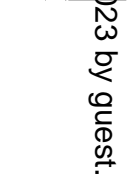 \\
\hline \multicolumn{6}{|c|}{$\begin{array}{l}\text { IV. OGULAR DIMENSIONS OF INDEX PATIENTS COMPARED DIREGTLY WITH } \\
\text { THOSE OF THEIR UNAFFEGTED SIBLINGS } \\
\text { A comparison was made between seven index patients and their unaffected siblings. } \\
\text { Satisfactory matching was achieved for age and refractive error, but not for sex. The }\end{array}$} & 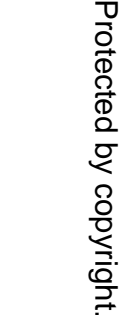 \\
\hline
\end{tabular}


glaucoma and of a group of normal controls matched for age (within +9 to -7 yrs), sex, and refraction (within $\pm \mathrm{r} \cdot 0$ dioptre). $\frac{\bar{a}}{3}$ value of $\mathcal{T}$ is shown together with the number of ranked pairs with a sign $(\mathcal{N})$ and the level ofsignificance of any difference found.은

\begin{tabular}{|c|c|c|c|c|c|c|c|}
\hline $\begin{array}{l}\text { Lens } \\
\text { thickness } \\
(\mathrm{mm} .)\end{array}$ & $\begin{array}{l}\text { Relative } \\
\text { lens } \\
\text { position }\end{array}$ & $\begin{array}{l}\text { Vitreous } \\
\text { length } \\
(\mathrm{mm} .)\end{array}$ & $\begin{array}{l}\text { Axial } \\
\text { length } \\
(m m .)\end{array}$ & $\begin{array}{l}\text { Length of } \\
\text { scleral } \\
\text { envelope } \\
(\mathrm{mm} .)\end{array}$ & $\begin{array}{l}\text { Applana- } \\
\text { tion } \\
\text { tension } \\
(\text { mm. } \mathrm{Hg})\end{array}$ & $\begin{array}{l}\text { Mean age } \\
\text { (yrs) }\end{array}$ & $\begin{array}{l}\text { Mean } \\
\text { refraction } \\
\text { (dioptres) }\end{array}$ \\
\hline $4 \cdot 9^{8 *}$ & $0 \cdot 237$ & $14 \cdot 50$ & $22 \cdot 22 *$ & 19.96 & $18 \cdot 57$ & $66 \cdot 57$ & $+1 \cdot 77$ \\
\hline 14 & 14 & 14 & 14 & 14 & 12 & 10 & I 3 \\
\hline I & $50 \cdot 3$ & $27 \cdot 5$ & 20 & 32 & 21 & $25 \cdot 5$ & $36 \cdot 5$ \\
\hline$<0.001^{*}$ & $<0.50$ & $<0.12$ & $<0.05^{*}$ & $<0.20$ & $<0.16$ & $<0.50$ & $<0.40$ \\
\hline $4^{\cdot 66^{*}}$ & $0 \cdot 24 I$ & $15 \cdot 00$ & $22 \cdot 87^{*}$ & $20 \cdot 45$ & $16 \cdot 36$ & $65 \cdot 21$ & $+1 \cdot 4^{1}$ \\
\hline
\end{tabular}

glaucoma and of a group of normal controls matched for age (within +9 to -7 yrs), sex, and refraction (within $\pm \mathbf{I} \cdot 0 \mathrm{w}$ dioptre). value of $\mathcal{T}$ is shown together with the number of ranked pairs with a sign $(\mathcal{N})$ and the level of significance of any difference found.

\begin{tabular}{|c|c|c|c|c|c|c|c|}
\hline $\begin{array}{l}\text { Lens } \\
\text { thickness } \\
(\mathrm{mm} .)\end{array}$ & $\begin{array}{l}\text { Relative } \\
\text { lens } \\
\text { position }\end{array}$ & $\begin{array}{l}\text { Vitreous } \\
\text { length } \\
(\mathrm{mm} .)\end{array}$ & $\begin{array}{l}\text { Axial } \\
\text { length } \\
(m m .)\end{array}$ & $\begin{array}{l}\text { Length } \\
\text { of scleral } \\
\text { envelope } \\
(\mathrm{mm} .)\end{array}$ & $\begin{array}{l}\text { Applana- } \\
\text { tion } \\
\text { tension } \\
(\mathrm{mm} . \mathrm{Hg})\end{array}$ & $\begin{array}{l}\text { Mean } \\
\text { age (yrs) }\end{array}$ & $\begin{array}{l}\text { Mean } \\
\text { refraction } \\
\text { (dioptres) }\end{array}$ \\
\hline $4 \cdot 45^{*}$ & 0.232 & $15^{\circ} 0$ & $22 \cdot 43$ & $20 \cdot 18$ & $14 \cdot 17$ & $38 \cdot 52$ & $+\quad 1.427$ \\
\hline 29 & 29 & 27 & 29 & 29 & 24 & 25 & 26 \\
\hline $100 \cdot 5$ & 220 & $148 \cdot 5$ & I 53 & 200 & 93 & I 12.5 & I $44^{\cdot 2}$ \\
\hline$<0.02^{*}$ & $<0.50$ & $<0.35$ & $<0.20$ & $<0.50$ & $0 \cdot 10$ & $<0.20$ & $<\quad 0.35$ \\
\hline $4 \cdot 24^{*}$ & 0.235 & $15 \cdot 29$ & $22 \cdot 77$ & $20 \cdot 67$ & 15.48 & $39 \cdot 5^{2}$ & $+1 \cdot 460$ \\
\hline
\end{tabular}

anterior chamber was shallower $(P<0 \cdot 01)$ and the lens position relatively further forware $(\mathrm{P}<0 \cdot 05)$ in the index patients than in their unaffected siblings.

\section{Discussion}

In this study careful matching of the subjects for age, sex, and refraction was considered essential, as these factors have been shown to have marked effects on the ocular dimensions measured. For instance, increasing age influences anterior chamber depth (Raeder $\bar{x}$ 
I922; Rosengren, I93I; Lowe, I970a), corneal radius (Marin-Amat, I956), corneal diameter (Priestley Smith, I89o; Storey and Phillips, I97 I), lens thickness (Priestley Smith, I883), relative lens position (Lowe, I970b) and applanation tension (Armaly, I 965 ; Hollows and Graham, I966). Over the age of 45 years, applanation tension is significantly greater in females than in males (Armaly, 1967b). Calmettes, Deodati, Huron, and Béchac (1966) have observed that the anterior chamber depth in females is shallower than in males of the same age. Between none of the samples compared was there a significant difference for age or refraction (see Tables I-III).

Some criticism may be levelled at the inclusion in the samples of glaucoma relatives, of subjects who were not related to the patients in the index groups. It was not possible to see the index patient of every glaucoma relative as some were excluded because of death, removal from the area, or operations which rendered them unsuitable for the measurement of ocular dimensions.

For the index sample the results of this study agree well with the findings of other workers. Anterior chamber depth and lens thickness were found to be significantly shallower and greater, respectively, in angle-closure glaucoma than in the normal, see Rosengren (1950), Törnquist (1956), Lowe (1968) and Storey and Phillips (197r). Our results also agreed with those of Lowe (1970a), who found that the lens is sited significantly further forward in angle-closure glaucoma than in the normal.

We found, as did Lowe (1969a) and Storey and Phillips (1971), that axial length of the eyeball was small in angle-closure glaucoma when compared to the normal. However, we found that the axial length of the scleral envelope did not differ significantly from that of the normal. This is at variance with the results of Storey and Phillips (197 I), who found a smaller scleral envelope in angle-closure glaucoma.

We found that corneal height was significantly less in angle-closure glaucoma patients, siblings, or their offspring, than in the normal. There was, however, no corresponding difference for the axial length of the scleral envelope. Our results, therefore, suggest that the structural abnormality in angle-closure glaucoma is in the anterior part of the eye, a conclusion also reached by Lowe (i 970a).

A smaller corneal radius in patients with angle-closure glaucoma than in the normal was suggested by data from Törnquist (1957), Grieten and Weekers (1962), and Lowe (1969a). No such difference was found in this study. This disparity may be due to our careful matching of refraction and use of a matched-pairs statistical test. We consider that a small corneal diameter (we did find this to be significantly smaller in patients with angle-closure glaucoma than in controls) may be more important than corneal radius in determining corneal height. Small corneal diameter in angle-closure glaucoma was also found by Grieten and Weekers (1962) and Storey and Phillips (1971).

The results of this study for the glaucoma relatives also agree well with previously published work. The presence of a shallow anterior chamber in the eyes of the relatives of patients with angle-closure glaucoma reported by Törnquist (1953), Kellerman and Posner (I955), and Paterson (I96I) is confirmed (Table II and III).

Our results suggest that corneal diameter, corneal height, and lens thickness contribute to the all-important shallowness of the anterior chamber in angle-closure glaucoma, and that these characteristics are shared by unaffected siblings and offspring although to a lesser degree. Our comparisons between patients with angle-closure glaucoma and normal subjects on the one hand, and between siblings of angle-closure glaucoma patients and normal subjects on the other hand, showed the same differences for the dimensions considered, with the exception of relative lens position. These findings, that the lens was 
significantly further forward in patients than in controls, but not differently sited in the siblings of patients than in controls, are consistent with the results of the comparison (see p. 48I) which showed that the lens was sited significantly more anteriorly in each of seven index patients, than in their unaffected siblings $(\mathrm{P}<0 \cdot 05)$. Assessment of relative lens position (Lowe 1970a; see his formula on p.478), involving anterior chamber depth, lens thickness, and axial length of eyeball, revealed a less clear difference between patients and their unaffected siblings $(\mathrm{P}<0 \cdot 05)$, than did anterior chamber depth alone (where the difference between patients and siblings was $\mathrm{P}<0 \cdot 0 \mathrm{I})$. Anterior chamber depth may therefore be just as useful or even more useful than relative lens position in discriminating between angle-closure glaucoma and normality.

\section{The argument for dominant inheritance}

Törnquist (1953), and Miller (1970) reviewing Törnquist's work, considered that the shallow anterior chamber in angle-closure glaucoma resulted from the action of a dominant gene. Törnquist (1953) found that the incidence of shallowness of the anterior chamber in patients with angle-closure glaucoma when compared to the normal was of the same order as that in their siblings or offspring. The assumption of a simple dominant transmission by a single gene would require the expected deviation away from the normal, as shown by the index patients, in 50 per cent. of siblings and offspring. The difficulty in analysing Törnquist's material is that of deciding at what level the anterior chamber depth is pathologically shallow. Miller (1970) considered that Törnquist's tentative explanation of dominant transmission might be accepted, bearing in mind that the depth of the normal anterior chamber is influenced by many genes which, together with environmental factors, determine the continuous variation, because it is likely that the effect of a major gene on chamber depth would be modified by other genes operating in the same developmental process. The same reasoning can be applied to lens thickness, corneal diameter, and corneal height, all of which show the same differences from the normal for the siblings and offspring in this study, as do the angle-closure glaucoma index patients when they are compared with the normal. On this basis it could be suggested that a single dominant gene may be responsible for the thick lens and small corneal diameter and height found in this form of glaucoma. This would be consistent with a dominant mode of transmission for the condition. If a single dominant gene were responsible for angle-closure glaucoma, correlations between corneal diameter, corneal height, and lens thickness, all of which determine anterior chamber depth, would be quite close, but we did not find this to be so. It must be admitted, however, that our samples were small. We did find an association between a shallow anterior chamber and a thick lens $(P<0 \cdot 05)$, but this may be explained by the age-dependence of each.

\section{The argument for multifactorial inheritance}

Clarke (1972) has pointed out that, in diseases of a multifactorial aetiology, first-degree relatives, i.e. siblings or offspring, will half resemble their affected relative because they have acquired half the total number of "pathological" genes from their parents. A multifactorial aetiology in angle-closure glaucoma could therefore be supported if, in respect of the ocular dimensions which have been shown to be important in this condition, a relative half resembled his affected first-degree relative and half resembled a normal control. If a dominant mechanism with roo per cent. penetrance of the gene were involved, half the siblings would be completely like their affected sibling and would display the 
condition, and half would be normal. Affected siblings of patients were, of course, excluded from our series.

An assessment of the degree of similarity of each unaffected sibling to his or her affected 을 sibling in contrast to the normal was possible in our data in seven instances, i.e. we had

(a) Seven index patients each of whom were matched for age and refractive error with; (b) one unaffected sibling from the same sibship

(c) a normal control. Unfortunately, matching for sex was not possible in three instances. A comparison was made of anterior chamber depth in these three matched groups, $(a),(b)$, and $(c)$, from the following formula:

A.C. depth of (a) index patient - A.C. depth of (b) sibling

A.C. depth of (a) index patient - A.C. depth of (c) normal control

A multifactorial aetiology could be supported if, in each of the seven comparisons of $(a)$ o with $(b)$ and $(c)$, the above ratio approached 0.5 , i.e. each unaffected sibling resembled $v$ equally an index patient and a normal control. For a dominant condition, the anterior $\mathrm{A}$ chamber depth of at least half of the unaffected siblings would be very similar to that of 0 the normal control and the above ratio would probably approach I 0 .

From the data it was calculated that the above ratio for each of the seven instances was twelve times more likely to be 0.5 than $\mathrm{I} \cdot \mathrm{O}$. The probability $\mathrm{P}$ corresponding to this is $0 \cdot 083$, i.e. not quite significant: $=0.05$ would be regarded as significant. Our results, although inconclusive, do support a multifactorial rather than a dominant aetiology. It is also possible that angle-closure glaucoma is a recessive condition and that our unaffected siblings were all heterozygotes, and thus half resembled both index patients and normals.

The question of resemblance between relatives in angle-closure glaucoma clearly needs further investigation.

A multifactorial aetiology would include environmental factors, such as the state of the body's nutrition, which probably affect the rate of growth of the lens. Increasing thickness and anterior displacement of the lens with increasing age are major factors in determining the depth of the anterior chamber. It is sometimes difficult to distinguish between "secondary" angle-closure glaucoma due to a cataractous or intumescent lens and "primary" angle-closure glaucoma. Nordmann ( 1965 ) described cataracts as "an hereditary exaggeration of physiological ageing", a view which might suggest that genetically determined derangements of lens metabolism which result in cataract, as well as environmental factors, could also play a part in the increased lens size found in some cases of angle-closure glaucoma. The importance of environmental influences in the aetiology of angle-closure glaucoma has been discusse $d$ by Lowe (1972).

In the presence of a thick, anteriorly sited lens, angle-closure is the more likely to occur if the corneal diameter and corneal height are small. It is likely that, in any given age group, corneal and lens dimensions are normally distributed, and it is the "pathological lower or upper "tails" or "cut-offs" of these distributions (i.e. lower values for corneal diameter and corneal height, and higher values for lens thickness) which are such important attributes of the eye in angle-closure glaucoma.

We have shown that, for index patients, their siblings, and offspring, these dimensions each differ from those of normal controls in a similar way. If a multifact orial aetiology is responsible in angle-closure glaucoma, the genetic determination of corneal dimensions may be independent of that of lens size. Environmental factors would influence the rate of 
increase in lens size. Random combinations of the ocular dimensions which have been incriminated, as well as random combinations of environmental factors which modify these dimensions with increasing age, might explain the variable and often low prevalence of angle-closure glaucoma in different pedigrees. Whether angle-closure glaucoma is a dominant or multifactorial condition remains an open question (Sorsby 1970), but perhaps the latter mechanism should be favoured.

\section{Summary}

A study of certain ocular dimensions in index patients with angle-closure glaucoma and in their first-degree relatives (siblings and offspring) is described. The value obtained for each dimension in each index patient or relative was compared with the value obtained for a normal subject of closely matched age, sex, and refractive error. Four dimensions were found to differ significantly from the normal in the index patients, siblings, and offspring; these were, anterior chamber depth, lens thickness, corneal diameter, and corneal height. The possible means of genetic transmission for these dimensions is considered and related to the suggested modes of inheritance for angleclosure glaucoma.

\section{References}

Aizawa, K. (1960) Acta Soc. ophthal.jap., 64, 869

ARMALy, M. F. (1965) Arch. Ophthal. (Chicago), 73, I I

1967a) Ibid., 77, 747
$($ I $967 \mathrm{~b}) \quad$ Ibid., 78, 187
BIRó, I. (1951) Ophthalmologica (Basel), 122, 228

calmettes, deodati, huron, and béchac (i966) Amer. 7. Optom., 43, 765 (trans. D. A. Pitts and M. Millodot)

ClARKE, C. A. (1972) Brit. med. F., I, 606

DAVENPORT, R. C. (1959) Trans. ophthal. Soc. U.K., 79, 3

delmarcelle, y., collignon-Brach, J., and luckyx-Bacus, J. (1969) Bull. Soc. belge. Ophtal., r52, 447

- - - - (1970) Arch. Ophtal. (Paris), 30, 291

FALCONER, D. s. (ig65) Ann. hum. Genet., 29, 5 I

FRANÇOIS, J., and hEINTZ-DE BREE, c. (1966) Amer. F. Ophthal., 62, Io67

GERNET, H., and Jürgens, v. (ig65) v. Graefes Arch. Ophthal., 168, 419

GRIETEN, J., and WEEKERS, R. (1962) Ophthalmologica (Basel), r43, 409

HOllows, F. C., and GRAHAM, P. A. (1966) Brit. F. Ophthal., 50, 570

Kellerman, L., and POSNER, A. (1955) Amer. F. Ophthal., 40, 68 I

LOWE, R. F. (196r) Trans. ophthal. Soc. Aust., 21, 65

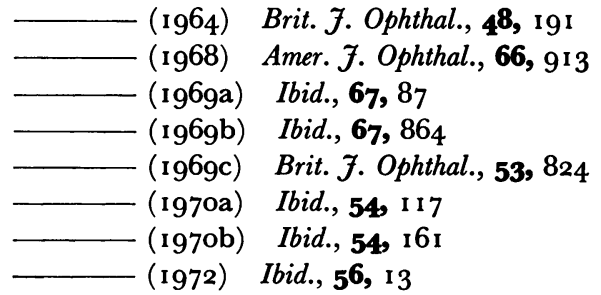

MARIN-Amat, м. (1956) Bull. Soc. belge Ophtal., no. 113, 25 I

MILLER, S. J. H. (1970) J. med. Genet., 7, 250

NORDMANN, J. (1965) Invest. Ophthal., 4o 384

PATERSON, G. (196I) Trans. ophthal. Soc. U.K., 81, 56 I 
Posner, A., and schlossman, A. (1949) Arch. Ophthal. (Chicago), 41, 125

Probert, L. A. (1952) Canad. med. Ass. F., 66, 563

RAEDER, J. G. (1922) v. Graefes Arch. Ophthal., I10, 73

ROSENGREN, B. (1930) Acta ophthal. (Kbh.), 8, 99

(193I) Ibid., 9, I03

- (1950) Arch. Ophthal. (Chicago), 44, 523

SIEGEL, s. (I956) "Nonparametric Statistics for the Behavioral Sciences", p. 75. McGraw-Hill,

New York

SMITH, PRIESTLEY (1883) Trans. ophthal. Soc. U.K., 3, 79

- (1890) Ibid., ro, 68

(I9I I) Ophthal. Rev., 30, 97

SORSBy, A. (1970) "Ophthalmic Genetics", 2nd ed., p. 36. Butterworths, London

- BENJAMin, B., DAVEY, J. B., Sheridan, M., and TANNER, J. M. (1957) 'Emmetropia and its

Aberrations'. Spec. Rep. Ser. Med. Res. Counc. No. 293. H.M.S.O., London

and Fraser, G. R. (1964) 7 . med. Genet., I, 47

- SHERIDAN, M., and LeARY, G. A. (I962) 'Refraction and its Components in Twins'. Spec.

Rep. Ser. Med. Res. Counc. No. 303. H.M.S.O., London

STENSTRÖM, s. (1948) 'Investigation of the Variation and Correlation of the Optical Elements of

Human Eyes', trans. D. Woolf. Amer. Acad. Optom. Monograph No. 58

StOREY, J. K., and PHILlips, C. I. (197I) Brit. J. physiol. Optics, 26, 228

SUGAR, H. s. (1941) Amer. F. Ophthal., 24, 851

TÖRNQUist, R. (1953) Acta ophthal. (Kbh.), Suppl. 39

(1956) Brit. 7. Ophthal., 40, $42 \mathrm{I}$

(I957) Ibid., 41, 42 I

vallance-owen, J. (1967) In "Modern Trends in Endocrinology 3", ed. H. Gardiner-Hill, p. I6o.

Butterworths, London

WAARdenburg, P. J. (1949) Ned. T. Geneesk., 93, 3603

WEekers, R., GOUgnard-Rion, G., and Gougnard, L. (1955) Bull. Soc. belge Ophtal., no. 110, p. 255 wilkie, J. s., Drance, s. M., and schulzer, m. (I969) Amer. $\mathcal{F}$, Ophthal., 68, 78 